This item was submitted to Loughborough's Research Repository by the author.

Items in Figshare are protected by copyright, with all rights reserved, unless otherwise indicated.

\title{
Collage as form and idea in the art criticism of Tristan Tzara
}

PLEASE CITE THE PUBLISHED VERSION

https://doi.org/10.1093/fs/knz180

\section{PUBLISHER}

Oxford University Press (OUP) @ The Author

\section{VERSION}

AM (Accepted Manuscript)

\section{PUBLISHER STATEMENT}

This is a pre-copyedited, author-produced version of an article accepted for publication in French Studies following peer review. The version of record BROWN, K., 2019. Collage as form and idea in the art criticism of Tristan Tzara. French Studies, 73 (4), pp.544-560 is available online at: https://doi.org/10.1093/fs/knz180.

\section{LICENCE}

CC BY-NC-ND 4.0

\section{REPOSITORY RECORD}

Brown, Kathryn. 2019. "Collage as Form and Idea in the Art Criticism of Tristan Tzara". Loughborough University. https://hdl.handle.net/2134/36906. 
The following version of the article is the one that was accepted for publication by French Studies (Oxford University Press) on 8 Feb, 2019. Scheduled publication: Jan 2020 (issue $74.1)$

\section{Collage as Form and Idea in the Art Criticism of Tristan Tzara Kathryn Brown}

Tristan Tzara's art criticism extended over a broad range of stylistically diverse twentiethcentury artists including James Ensor, Henri Rousseau, Pablo Picasso, Henri Matisse, Ivan Puni, Paul Klee, Hans Arp, Kurt Schwitters, Max Ernst, and Joan Miró among others. Attesting to the poet's wide-ranging interest in visual creativity, substantial essays were also devoted to African, pre-Columbian, and Oceanic arts. These art critical writings appeared in newspapers, exhibition catalogues, and journals between 1925 and 1961. Although Tzara had outlined plans to collect and publish his essays under the title Le Pouvoir des images, the project remained incomplete at the time of his death in $1963 .{ }^{1}$

Scholarship has tended to focus on Tzara's leading role in Dada to the detriment of his later writings. Yet consideration of the poet's works from the 1930s to the end of his career - in particular, his art criticism — offers a broader perspective on the contribution that Tzara made to theoretical debates about both literature and painting and their respective social roles. ${ }^{2}$ The aim of this article is to examine a style of image production that, in Tzara's view, eroded boundaries between media and contributed to the emergence of a 'modern mythology' in European art and society: collage. ${ }^{3}$ For Tzara, collage was important not just as a style of making (a form), but also as an idea that demonstrated a powerful way in which

${ }^{1}$ The essays were published in the order and with the title envisaged by the poet in Tristan Tzara, Euvres complètes, vol. 4 1947-1963, ed. by Henri Béhar (Paris: Flammarion, 1980), pp. 297-440. Subsequent references to Tzara's Euvres complètes are abbreviated to OC.

${ }^{2}$ Stephen Forcer discusses the implication of this critical focus on the early part of Tzara's œuvre in Modernist Song: The Poetry of Tristan Tzara (Oxford: Legenda, 2006), pp. 1267.

${ }^{3}$ The term 'mythologie moderne' is taken from one of Tzara's essays on Henri Rousseau discussed in the second part of this article: 'Le rôle du temps et de l'espace dans l'œuvre du Douanier Rousseau', $O C$ 4, pp. 337-44 (p. 344). 
art could regenerate social relations. Illustrating the claim that readers would look in vain for any 'rupture' that divided his creative persona into periods 'before and after' Dada, Tzara's close engagement with collage testifies to the underlying unity of his aesthetic and embeds his critical thinking in broader twentieth-century debates about the relationship between visual art, poetry, and theatre. ${ }^{4}$

Collage is a style of visual production that is associated with many major European art movements of the early twentieth century, including Cubism, Futurism, Dada, and Surrealism. As a revolutionary form of making that ranged from pasting pieces of paper, card, or newsprint on a two-dimensional surface (papier collé) to the incorporation of fabrics, photographs, printed ephemera, or entire objects into large-scale, multi-media constructions, collage challenged ideas about the types of material from which art could be produced and the ways in which works in visual media drew from, and connected to, reality. As Elza Adamowicz notes, by giving rise to fragmented, heterogeneous, and often transgressive forms, the 'collage principle' has been interpreted by many scholars and artists 'as the principal actant in the history of modern art'. 5 This article will argue that, for Tzara, the expressive and symbolic power of collage had the potential to impact life beyond the boundaries of the art world. Taking as key reference points Tzara's 1931 essay 'Le Papier collé ou le proverbe en peinture', his prose work Grains et Issues of 1935, and his critical writings on Picasso and Henri Rousseau published between 1935 and 1951, I shall argue that collage served as a template for the poet's reconception of both social relations and the psychic life of the individual.

\footnotetext{
${ }^{4}$ Letter from Tzara to Sacha Pana, 17 January 1934 quoted in $O C$ 1, p. 632. See also Fernand Drijkoningen's discussion of the unity of Tzara's aesthetic in 'Entre Surréalisme et Marxisme: Révolution et poésie selon Tzara', Mélusine, no. 1 (Lausanne: Éditions L’Age d'homme), 1980, pp. 265-80 (p. 266). Franck Knoery makes the point that Tzara's art criticism and essays of the 1930s can be understood as a development of the magazine format favoured by the poet in the early years of Dada. See Frank Knoery, 'Les revues littéraires et artistiques. Trajectoires de Tristan Tzara', in Tristan Tzara: L'homme approximatif (exh. cat.), ed. by Serge Fauchereau (Strasbourg: Édition des Musées de Strasbourg, 2015), pp. 192-205.

${ }^{5}$ Elza Adamowicz, Surrealist Collage in Text and Image: Dissecting the Exquisite Corpse (Cambridge: Cambridge University Press, 1998), p. 14.
} 
This argument is consistent with the ideas that had motivated Tzara's earliest commitment to Dada. As Stephen Forcer has noted, Dada made important contributions to ideas beyond the textual and can be seen 'to animate and expand debates about a diverse range of other fields, including poetics, psychoanalysis, ethics, semantics, intellectual history and science'. ${ }^{6}$ The following discussion will show that Tzara's conception of collage is similarly expansive. By elevating collage to the status of a metaphysical principle, Tzara distinguished his writings on this subject from those of his contemporaries and guaranteed an exceptional place for this style of making within twentieth-century creative and intellectual life.

\section{Collage as Form}

'Le papier collé ou le proverbe en peinture' was one of Tzara's first and most important commentaries on collage. Published in Christian Zervos's leading art journal, Les Cahiers $d$ 'art, the essay was accompanied by reproductions of collages that had been produced by Picasso, Braque, Arp, Miró, Schwitters, Juan Gris, Henri Laurens, and Louis Marcoussis between 1913 and 1930 (Fig. 1). Visually, therefore, the essay showcased the development of collage from early Cubism to Miró's compositions of the late 1920s in which rumpled pieces of pasted paper were combined with minimalist charcoal lines. ${ }^{7}$

Tzara's approach to this subject developed ideas that Louis Aragon had put forward in a catalogue essay, 'La Peinture au défi', that had been published to accompany an exhibition of collages at the Galerie Goemans in Paris in $1930 .{ }^{8}$ Like Aragon, Tzara was keen to explore the role of collage at the intersection of verbal and visual media. The title of the essay gives a sense of the direction to be taken in the ensuing discussion: collages

\footnotetext{
${ }^{6}$ Stephen Forcer, Dada as Text, Thought and Theory (Oxford: Legenda, 2015), p. 3.

${ }^{7}$ For discussion of Miró's collages of the late 1920s see Jacques Dupin, Miró (Paris: Flammarion, 2012), pp. 154-8.

${ }^{8}$ Tzara, 'Le papier collé ou le proverbe en peinture', $O C$ 4, pp. 375-60. The original essay was published in Cahiers d'Art, no. 2, 1931, pp. 61-4. Aragon's essay is reprinted in Louis Aragon, Les Collages (Paris: Hermann, 1980), pp. 37-77. For further discussion of Aragon's conception of collage see Adamowicz, Surrealist Collage in Text and Image, p. 10.
} 
make use of familiar words or phrases ('proverbs') that are dislodged from their usual semantic function and made to signify differently in their new visual context. As scholars have noted, this visual and linguistic 'dépaysement' was a staple of both Dada and Surrealist ideas about the liberating potential of collage. ${ }^{9}$ In keeping with this premise, Tzara's essay opens with a discussion of the limits of linguistic expression. According to Tzara, thought is held in check by familiar patterns of referentiality and grammatical codes. Individual words are encased in a 'trop solide carapace' that guarantees a stable, but 'lazy' logical foundation for human thought and interaction. ${ }^{10}$ The practice of verbal collage in poetry is envisaged as a means by which to break such habits of expression. Tzara argues that by inserting 'autonomous blocks of language' or non-linguistic symbols into the poetic line, conventional patterns of sense can be deflected and thought will be elevated to 'des transparences insoupçonnées'. ${ }^{11}$

Turning his attention to visual expression, Tzara explains that collage in painting plays an analogous role by reconfiguring the relationship between the space of the artwork and that of the viewer. With its roots in the world of everyday things, collage is a style of creativity that can, Tzara claims, bring the viewer into 'une plus grande intimité avec les vérités quotidiennes'. ${ }^{12}$ Dispensing with aspirations to mimesis, visual art integrates ordinary objects into the visual field and thereby blurs the boundary between real and fictional space:

Une forme découpée dans un journal et intégrée dans un dessin ou un tableau y enveloppe le lieu commun, le morceau de la réalité quotidienne, courante, par rapport à la réalité construite par l'esprit. ${ }^{13}$

\footnotetext{
${ }^{9}$ Adamowicz, Surrealist Collage in Text and Image, pp. 74-5; Philippe Moret, Tradition et modernité de l'aphorisme: Cioran, Reverdy, Scutenaire, Jourdan, Chazal (Geneva: Droz, 1997) pp. 184-7; Marie-Paule Berranger, Dépaysement de l'aphorisme (Paris: Corti, 1988), p. 215.

10 Tzara, 'Le papier collé ou le proverbe en peinture', p. 358.

${ }^{11}$ Ibid., p. 358

12 Ibid., p. 360.

${ }^{13}$ Ibid., p. 358.
} 
In this account, the intrusion of a visual 'commonplace' ('le lieu commun') interrupts the seamlessness of the world depicted on the material support and troubles the way in which the artwork generates meaning. As Marjorie Perloff notes, a collaged element on a work's surface serves a 'double function' by simultaneously referring to an external reality and undercutting 'the very referentiality it seems to assert'.${ }^{14}$ Paradoxically, it is simultaneously part of, but external to, the thing it represents.

For Tzara, this combination of material unevenness and referential disruption was central to the emancipatory potential of collage. In both painting and poetry, collaged words and materials could 'divert' existing paths of sense and thereby undermine familiar modes of expression. According to Tzara, collage was neither a 'quotation' of reality, nor a means of signifying it. ${ }^{15}$ Rather, it was the eruption of the everyday ('le morceau de la réalité quotidienne') into the fiction created by the mind ('la réalité construite par l'esprit'). ${ }^{16}$ The positive upshot of this process was the inauguration of an alternative and unpredictable system of signification that created a new world ('une réalité unique') from objects that remained anchored in the everyday. ${ }^{17}$ In 'Les papiers collés de Picasso' of 1935, Tzara summed up this transformation when he noted that a piece of white paper cut from, and pasted onto, the same piece of white paper underwent more than a merely perceptible change. Rather, it gave rise to an independent 'poetic' world: 'Le moyen et l'expression de l'œuvre se confondent pour donner naissance à quelque chose de plus que l'œuvre réalisée. C'est un pur résidu nommé poésie fondu dans l'œuvre d'art dont il faudra, nécessairement,

${ }^{14}$ Marjorie Perloff, 'Collage and Poetry', in Encyclopedia of Aesthetics, ed. by Michael Kelly, 4 vols (Oxford: Oxford University Press, 1998), vol. 1, pp. 384-7.

${ }^{15}$ Aragon explores the idea of collage as quotation in an essay of 1965 'Collages dans le roman et dans le film'. Aragon, Les Collages, pp. 113-36 (p. 131).

16 'Le papier collé ou le proverbe en peinture', p. 358. This discussion of the collaged surface develops the distinction that Tzara makes between 'la pensée dirigée' and 'la pensée non-dirigée' in his 'Essai sur la situation de la poésie' of 1931.

17 Tzara, Le papier collé ou le proverbe en peinture', p. 358: ‘...une réalité unique dans un monde crée par la force de l'esprit et du rêve'. 
rechercher la nature quand il s'agira d'en approfondir le sens' (emphasis as per the original). ${ }^{18}$

The stress on rerouting referentiality for the purpose of creating a different, but oddly familiar space was not unusual in art critical discussions about collage in the first half of the twentieth century. Adamowicz points out that from the 1920s onwards, it was common to identify this process as an act of 'reworlding' in art. ${ }^{19}$ She notes Aragon's semiotic approach in 'Max Ernst, peintre des illusions' of 1923, in which the author writes: 'Toute apparence, notre magicien la recrée. Il détourne chaque objet de son sens pour l'éveiller à une réalité nouvelle'. ${ }^{20}$ Tzara adopted a similar formulation in 'Le Papier collé ou le proverbe en peinture' when he described linguistic collage as an attempt to 'greffer un sens nouveau aux mots qu'on détourne de leur direction habituelle' (emphasis added). ${ }^{21}$ Other artists and writers adapted the notion of 'détournement' to suit their own expressive purposes. In an even stronger formulation, the Berlin-based Dadaist Hannah Höch described collage as a means by which elements from contrasting realms (including music and dance) could be 'alienated' from their usual function for the purpose of generating 'a newly created entity'. ${ }^{22}$ For Max Ernst, adopting ideas expressed by Pierre Reverdy and André Breton in their writings on Surrealism, collage enacted the 'systematic displacement' of objects for the purpose of staging 'the chance meeting of two distant realities on an unfamiliar plain'. ${ }^{23}$

${ }^{18}$ Tzara, 'Les papiers collés de Picasso', p. 362. Tzara takes up this theme in 'Picasso et l'homme à l'agneau' when he writes: 'L'art n'est pas imitation de la vie; il est une création parallèle'. OC 4, pp. 377-9 (p. 378).

${ }^{19}$ Adamowicz, Surrealist Collage in Text and Image, p. 68.

${ }^{20}$ Louis Aragon, 'Max Ernst, peintre des illusions', Les Collages, p. 30.

${ }^{21}$ Tzara, 'Le papier collé ou le proverbe en peinture', p. 358.

${ }^{22}$ Hannah Höch, 'On Collage', in The Ends of Collage, ed. by Yuval Etgar, trans. Naomi Vogt (London: Luxembourg \& Dayan, 2017), pp. 42-3 (p. 43).

${ }^{23}$ Max Ernst, 'Preface to The Hundred-Headed Woman', in The Ends of Collage, ed. Etgar, trans. Vogt, p. 128. Ernst's formulation echoes Reverdy's famous discussion of the poetic image as a 'rapprochement de deux réalités plus ou moins éloignées' in 'L'Image' (NordSud, no. 13, March, 1918), reprinted in Pierre Reverdy, Euvres complètes, vol. 1, ed. by Étienne-Alain Hubert (Paris: Flammarion, 2010), pp. 495-6 (p. 495). See also André Breton, 'Manifeste du surréalisme' (1924), Euvres complètes, ed. by Marguerite Bonnet, 
Like his Surrealist counterparts, Tzara emphasized the power of collage to divert sense for the purpose of creating 'une réalité unique'. ${ }^{24}$ His approach to this topic differed from that of his contemporaries, however, in so far as he also emphasized the reciprocal relationship between collage and the visual environment from which materials are taken. ${ }^{25}$ For Tzara, the act of 'reworlding' associated with collage did not simply take place in the artwork, but also on the city street. Focusing on the ephemeral presence of posters in public spaces, he drew a parallel in his 1931 essay between art and urban culture. City spaces are, he argues, an admixture of paper advertisements that spontaneously give rise to new visual forms. Subject to erosion by the elements and to vandalism by passers-by, advertising posters are slowly unmoored from the products they are designed to sell and cohere unexpectedly into new visual and sculptural forms ('un torse éblouissant') within the city (Fig. 2):

Arrosés par les pluies, les tempêtes ou le soleil, la formule caractéristique, le signe ou la couleur, éveillent un simulacre de culte ancien, d'un culte depuis longtemps disparu de la circulation humaine, dans cette partie de l'homme où les étincelles s'allument encore bien vite, et dirigent la raison et ses désirs. ${ }^{26}$

with Philippe Bernier, Étienne-Alain Hubert and José Pierre (Paris: Gallimard, Bibliotheque de la Pléiade, 1988), vol. I, pp. 309-46 (p. 324).

24 Tzara, 'Le papier collé ou le proverbe en peinture', p. 358.

${ }^{25}$ Ibid.

${ }^{26}$ Ibid., p. 359. Elmer Peterson notes an overlap between this image of the city street and Guillaume Apollinaire's 'Zone' of 1913, a poem in which handbills and posters combine to form 'la poésie de ce matin'. Peterson points out, however, that in contrast to Apollinaire's search for beauty in quotidian experience, Tzara's image expresses the idea that poetry resides in 'l'élément de la vie' that neither manifests beauty nor has any aspiration to it. Elmer Peterson, Tristan Tzara: Dada and Surrational Theorist (New Brunswick: Rutgers University Press, 1971), p. 86; Guillaume Apollinaire, 'Zone', Euvres poétiques, ed. by Marcel Adéma and Michel Décaudin (Paris: Gallimard, Bibliothèque de la pléiade, 1965), p. 39. 
Echoing the creative spontaneity championed in the early years of Dada, the impromptu metamorphosis of urban poster culture gives rise to an independent form of symbolism (or 'myth') that appeals to, and is expressive of, collective consciousness. The collaged canvas mimics this mysterious visual transformation of the city street by generating unexpected, layered surfaces from mass media texts and images. ${ }^{27}$ While Walter Benjamin argued in 1935 that the mechanical reproduction of images had 'separated art from its basis in cult', Tzara pursued the contrasting idea that collage - with its explicit connection to mass produced signs and popular culture - awakened 'de nouvelles superstitions' that could flourish in quotidian life. ${ }^{28}$

In Tzara's view, the images that circulated on and between the city street and the canvas were slowly freed from the capitalist logic of their underlying advertising material. His reference to the presence of a 'lieu commun' in collage should, therefore, be understood in a dual sense. It does not simply refer to a collaged element as the incursion of a 'commonplace' or 'platitude' into an artwork, but also signals the emergence of a unique space that is shared by museum and street, fiction and reality, artist and viewer. For Tzara, the incorporation of ordinary materials into an artwork harnesses a generative process that takes place within the urban environment and stages a recuperation of the visual commons. By constituting a vital site of exchange between art and the everyday, collage could function, therefore, as a powerful signal of art's democratic potential.

The social implications of collage were not, however, simply rooted in ideas about the need to undermine circuits of capital exchange. Rather, by evidencing physical acts of tearing, cutting, and pasting, the collaged surface staged a 'visual transfer' of humankind's instinctive sensory responses to the world. ${ }^{29}$ Drawing on Jungian psychology, Tzara

27 On the broader role of mass media advertising in Tzara's works see Katherine Papachristos, L'Inscription de l'oral et de l'écrit dans le théâtre de Tristan Tzara (New York: Peter Lang, 1999), pp. 73-5.

${ }^{28}$ Walter Benjamin, 'The Work of Art in the Age of Mechanical Reproduction', in: Illuminations, ed. Hannah Arendt, trans. Harry Zorn (New York: Schocken Books, 1969), p. 8. Tzara, 'Le papier collé ou le proverbe en peinture', p. 359. On collage's connection to mass culture, see also Christine Poggi, In Defiance of Painting: Cubism, Futurism, and the Invention of Collage (New Haven and London: Yale University Press, 1992), pp. 253-6.

29 Tzara, 'Les papiers collés de Picasso', p. 362. 
envisaged collage as a counter to cognitive engagement with both the realm of art and the space of the city. As a form of creativity that engaged the whole body, collage could unleash desires anchored in the collective unconscious for the purpose of triggering 'un mode de penser nouveau, les bases sur lesquelles l'homme retrouvera le domaine de la joie et de son plaisir immédiat' ${ }^{30}$ For Tzara, collage liberated pictures from a purely visual realm, thereby restoring both artist and viewer to sensory plenitude and initiating a new set of shared 'rites' in modern society.

In 'Picasso et les chemins de la connaissance' of 1947, Tzara developed this point by emphasizing the ability of collage to construct a newly embodied spectator who enjoys a form of 'toucher visualisé'. ${ }^{31}$ Importantly for the purposes of the present discussion, the same essay draws a connection between 'tactilisme à travers la vision' and theatrical performance. ${ }^{32}$ Akin to the creation of a 'lieu commun' in a collaged canvas, the theatre was for Tzara, a multi-sensory space of spontaneous gesture shared by actor and spectator. It was also a place in which elements drawn from different spatial and temporal frameworks could be juxtaposed and compressed. As Philippe Dagen has noted, by drawing a connection between works on canvas and those on stage, Tzara posited 'une unité qui transcend la distinction ordinaire entre deux modes d'expression profondément différents, l'un dans le temps, l'autre sur la surface, l'un par la parole, l'autre par les lignes et les couleurs'. ${ }^{33}$ Significantly, it was by analyzing the theatrical works of a painter, Henri 'Le Douanier' Rousseau, that Tzara developed this connection between contrasting media and the sensory experiences with which they were associated. As I shall argue in the following section, in his analysis of the structure of Rousseau's plays and paintings, Tzara also showed how the idea of collage could stimulate a powerful reconceptualization of individual psychology.

${ }^{30}$ Tzara, 'Le papier collé ou le proverbe en peinture', p. 359 and 'Les papiers collés de Picasso', p. 363. Arguably, this brings Tzara's conception of collage close to Surrealism's privileging of pleasure, parody and humour. See Adamowicz, Surrealist Collage in Text and Image, p. 75.

${ }^{31}$ Tzara, 'Picasso ou les chemins de la connaissance', pp. 364-76 (p. 374). See also 'Le papier collé ou le proverbe en peinture', p. 358.

32 Ibid., p. 370.

${ }^{33}$ Philippe Dagen, 'Un objet de nécessité supérieure. Tzara et l'art', Europe, no. 1061-62 (Sept-Oct.), 2017, pp. 109-16 (p. 112). 


\section{Collage as Idea}

In 1965, Louis Aragon published a short essay, 'Petite note sur les collages chez Tristan Tzara et ce qui s'en suit', in which he describes his former Dada colleague as 'l'un des practiciens les plus remarquables de l'esprit de collage' (emphasis added). ${ }^{34}$ Aragon begins by discussing the linguistic innovations of Tzara's early poetry, including the introduction of 'unpronounceable signs' into the poetic line. Linking the graphic revolutions of Dada poems and manifestos to the development of collage in painting, he describes collage as an expressive medium that does not simply draw on contrasting sign systems, but that compresses different works of art into a single entity. In support of this analysis, he discusses Tzara's incorporation of scenes from Shakespeare's Hamlet into his own play Mouchoir de Nuages (1924) and describes the resulting theatrical collage as a creative 'abbreviation' (abrégé) of a pre-existing artwork. ${ }^{35}$

Aragon was right to understand this twinned notion of appropriation and juxtaposition as crucial to Tzara's broader conception of collage and its potential for performance. Taking up Aragon's description of Tzara as a practitioner of the 'spirit' of collage, this section will consider the latter's elaboration of these ideas in his discussion of two plays written by Henri Rousseau. I shall draw a connection between the conception of collage elaborated in Tzara's 'Le papier collé ou le proverbe en peinture' discussed above and his analysis of the treatment of space and time in theatre. The relationship between the two will illuminate Tzara's ideas about the ways in which collage can not only usher in new forms of theatrical performance, but also profoundly alter the individual's conception of the temporal trajectory of his or her own life. Tzara probes this idea in Grains et Issues of 1935 ,

${ }^{34}$ Louis Aragon, 'Petite note sur les collages chez Tristan Tzara et ce qui s'en suit', in Louis Aragon, Les Collages (Paris: Hermann, 1980), pp. 149-57 (p. 149).

${ }^{35}$ See also Corinne Contini-Flicker's 'Mouchoir de Nuages (1924) de Tzara, collage de Hamlet: une réécriture Dada', in Poétiques de la discontinuité de 1870 à nos jours, ed. by Isabelle Chol (Clermont-Ferrand: Presses Universitaires Blaise Pascal, 2004), pp. 283-302; and Papachristos, L'Inscription de l'oral et de l'écrit dans le théâtre de Tristan Tzara, pp. $71-3$. 
a work that bridges his discussion of papiers collés and his later ideas about the compression of time and space in Rousseau's works.

In the early decades of the twentieth century, Henri Rousseau's art captured the imagination of the Parisian avant-garde. Picasso acquired several of Rousseau's canvasses and hosted the famous banquet in honour of the painter in Paris in 1908. ${ }^{36}$ Apollinaire devoted a substantial essay to the topic of Rousseau's art in 1914, and Robert Delaunay acquired the manuscripts of two plays that Rousseau had written between the late 1880s and the end of the century: Une visite à l'exposition de 1899 and La vengeance d'une orpheline russe. Tzara, in turn, acquired these manuscripts from Sonia Delaunay in 1945. A third play by Rousseau, L'Étudiant en goguette, fell into the hands of the painter's landlord and was acquired by Tzara from the latter's widow. ${ }^{37}$ Against this background, Tzara's interest in Rousseau's work was as much an act of self-placement in relation to his avant-garde contemporaries as it was to Rousseau's distinctive creativity.

Tzara wrote two essays that have a bearing on Rousseau's theatre and painting. The first, 'Le théâtre d'Henri Rousseau' was the preface to an edition of Une visite à l'Exposition de 1889 that Tzara published in 1947. ${ }^{38}$ The second, 'Le rôle du temps et de l'espace dans l'œuvre du Douanier Rousseau' was published in a catalogue that accompanied an exhibition of Rousseau's paintings at the Sidney Janis Gallery in New York in 1951.39

As commentators have noted, early twentieth-century art criticism focused primarily on Rousseau's personality and presented the artist's œuvre in ways that were designed to highlight its unconventionality. Insistence was placed on the fact that Rousseau was selftaught, had spent most of his career as a Parisian customs official, and had given music lessons towards the end of his life in the hope of increasing his income. The themes of his

\footnotetext{
${ }^{36}$ For discussion of this banquet and Picasso's interest in Rousseau's works see Peter Read, Picasso \& Apollinaire: The Persistence of Memory (Berkeley: University of California Press, 2008), pp. 46-8.

${ }^{37}$ Nancy Ireson discusses the circumstances that led to Tzara's acquisition of this and the other manuscripts in 'Tristan Tzara and the plays of the Douanier Rousseau', The Burlington Magazine, September 2004, CXLVI, pp. 616-21 (p. 616).

${ }^{38}$ Tzara, 'Le théâtre d'Henri Rousseau', $O C$ 4, pp. 345-56.

39 Tzara, 'Le rôle du temps et de l'espace dans l'œuvre du Douanier Rousseau', OC 4, pp. 337-44. The Sidney Janis Gallery presented an exhibition on international Dada in 1953.
} 
works - notably the depiction of tropical forests - and their naïve compositional style also contributed to myths about Rousseau's 'outsider' status. In an interview of 1910, Arsène Alexandre emphasized 'la ruse candide du sourire' and the 'bonheur enfantin' of the painter. ${ }^{40}$ For Apollinaire, there was 'aucun maniérisme, aucun procédé, aucun système' to be found in the works of 'le mirifique Rousseau'. ${ }^{41}$ Although other writers including Jarry and Cocteau, signaled the importance of Rousseau to the early twentieth-century avantgarde, Philippe Soupault concluded that even by the 1960s 'la légende qui le fait traiter d'aliéné, de naïf, de farceur et de primaire n'est pas encore détruite' ${ }^{42}$

In the 1940s and 50s Tzara helped to reorient this debate by examining the structural qualities of Rousseau's works. The compression of space and time in Rousseau's painting became the clue to understanding his approach to theatre. In his commentary on a canvas of 1908 Les Joueurs de football (Fig. 3) Tzara notes: 'Le statisme de ses tableaux n'est que la conséquence de la décomposition du mouvement en éléments indépendants, véritables tranches de temps, liés les uns aux autres par une sorte d'opération arithmétique'. ${ }^{43}$ The work depicts four men playing football, yet there is little sense of continuity in the action. Whether an image of two men is repeated or whether the work depicts different moments within a single game or multiple games (including potentially other sports, for example,

${ }^{40}$ Arsène Alexandre, 'La vie et l'œuvre d'Henri Rousseau. Peintre et ancient employé de l'octroi. Entretien avec Arsène Alexandre', Comøedia, 3 April, 1909, p. 3. Reprinted in Le Douanier Rousseau par ses contemporains: Critiques, écrits, entretiens, essais, monographies, souvenire, témoignages, ed. by Raoul Coquereau (Toulouse-Paris: Édition Ombres, 2016), pp. 65-70 (p. 70 and p. 71).

${ }^{41}$ Guillaume Apollinaire, 'Le Douanier', Euvres en prose complètes, vol. II, ed. by Pierre Caizergues and Michel Décaudin (Paris: Gallimard, Bibliothèque de la pléiade, 1991), pp. 627-41 (p. 638 and p. 627).

${ }^{42}$ Philippe Soupault, 'Henri Rousseau, le Douanier', in Profils perdus (Paris: Mercure de France, 2015), pp. 105-12 (p. 112). For further discussion of the reception of Rousseau's works over the course of the twentieth century and the mythologizing of his character see Gabriella Belli and Guy Cogeval, 'Rousseau, or About Archaic Naiveté', in Henri Rousseau: Archaic Naiveté (exh. cat.), ed. by Gabriella Belli and Guy Cogeval (Milan: 24 ORE Cultura, 2015), pp. 21-9.

43 Tzara, 'Le rôle du temps et de l'espace dans l'œuvre du Douanier Rousseau', p. 341. 
boxing), the compressed action, restricted space, and unconventional perspective imbues each segment of the canvas with its own structural independence. Anticipating the look of Magritte's 'collaged paintings' of the 1920s, Les Joueurs de football, like many of Rousseau's works, juxtaposes independent elements that defy spatio-temporal logic. ${ }^{44}$

A similar point could be made about Rousseau's self-portrait, Moi-même, portraitpaysage (Fig. 4), a painting that Tzara identified as a summation of Rousseau's entire art. ${ }^{45}$ The work has a troubling perspective (the discrepancy between the size of the central figure and the bystanders on the left), and Rousseau himself seems to be floating just above the ground. Applying Tzara's notion of collage as the simultaneous presence of competing spatial and temporal elements in a single framework, one might ask whether the painter truly inhabits this scene. As the double-barreled title suggests, the work is not a straightforward self-portrait, but rather two works layered on top of each other: a portrait and a landscape

In his analysis of space and time in Rousseau's works, Tzara raises an issue that is crucial to ideas about how paintings communicate to the viewer, namely: can the action of a picture be unfolded in linear time as if it were a narrative? Considering this problem from the perspective of analytic aesthetics, David Carrier answers in the affirmative. He argues that as a general rule viewers try to 'animate' figurative paintings by imagining a 'before' and 'after', and that the act of interpretation itself is a 'setting into action' of the depicted scene. ${ }^{46}$ For Carrier, much twentieth-century painting subverts that operation, and he cites Matisse's Luxe, calme et volupté (1904, Musée national d'art moderne, Centre Pompidou, Paris) as an example of a painting that, although figurative, resists the imposition of a definitive narrative.

Tzara offers a different perspective on this problem by drawing on ideas expressed in his essays about collage. He argues that the characters in Rousseau's works occupy a single pictorial space, but that they do not share the same temporal space (or, by extension, a continuous, linear narrative). As Tzara notes in connection with Les Joueurs de football,

${ }^{44}$ For discussion of Magritte's collaged paintings see Patricia Allmer, René Magritte: Beyond Painting (Manchester: Manchester University Press, 2010), p. 120. 45 Ibid., p. 342.

${ }^{46}$ David Carrier, 'Luxe, calme et volupté', in Source: Notes in the History of Art, vol. 17, no. 1 (Fall, 1997), pp. 34-8. 
'chaque secteur de la composition garde son intégrité indépendente et sa vie propre' ${ }^{47}$ Like collaged materials on a canvas, Rousseau's works display a rupture in the structural continuity of the depicted subject. By virtue of this style of execution, the paintings have the appearance of collages: 'Le principe de juxtaposition et de simultanéité qui régit sa peinture, où les lieux communs sont sublimés et dépassent leurs limites conventionelles, Rousseau l'a trouvé instinctivement...' ${ }^{48}$ Les Joueurs de football is interpreted as a scene that has been metaphorically 'cut out' from competing narratives and then 'pasted' together on the surface of a single object. Echoing the notion of 'détournement' pursued in 'Le papier collé ou le proverbe en peinture', Tzara idenitifes the juxtaposition of clashing elements as the means by which a visual commonplace ('lieu commun') is incorporated into, and surpassed within, the artwork.

This structural feature of Rousseau's art has important consequences for the kinds of stories told by the works. If, for Tzara, Rousseau's paintings depict independent slices of time 'in a dramatic sequence', this is not equivalent to the linear unfolding of a story that answers questions about what happened before and after the depicted moment. In contrast to the portrayal of continuous movement in the manner of, for example, Marcel Duchamp's $\mathrm{Nu}$ descendant un escalier no. 2 (1912, Philadelphia Museum of Art), Tzara alerts the viewer to the simultaneous presence of multiple spatio-temporal frameworks within a single visible surface. It is this juxtaposition of discontinuous elements that, for Tzara, constitutes the 'modern character' of Rousseau's art. ${ }^{49}$ Yet Tzara does not draw this conclusion simply by interpreting the visual style of Rousseau's paintings. Rather-in a kind of critical collage - he turns to Rousseau's theatre in order to explain this idea.

In his commentary on Rousseau's short melodrama La vengeance d'une orpheline russe, Tzara emphasizes the alternation of scenes. In the first act, the plot follows the action in two houses with contiguous gardens; the action in one house is held in suspense, while the action in the other is presented to the audience. For Tzara, this alternation suggests an analogy with cinema: 'La liaison entre les scènes est laissée sur le compte de la mémoire,

\footnotetext{
47 Tzara, 'Le théâtre d'Henri Rousseau', p. 346.

48 Ibid., p. 351.

${ }^{49}$ See also Ireson's discussion of 'simultaneity' in Tzara's essays and the dialogue that this implied with works by Sonia and Robert Delaunay in 'Tristan Tzara and the plays of the Douanier Rousseau', pp. 619-20.
} 
toutes étant présentes simultanément et chaque partie devant être regardée à tour de rôle'. ${ }^{50}$ Tzara emphasizes cuts in the visible action as the viewer's attention is directed to different locations. The drama contains points of suspension that permit the unfolding of uneven sequences that contain more than they show. ${ }^{51}$

Une visite à l'exposition opens up a related perspective: the comedy traces the visit of a family from Brittany to Paris and culminates in their tourist route around monuments of the capital. In the final act, the family members find themselves in a short space of time at the Madeleine, Les Invalides, the Place de la République, the Grands Boulevards, and the Jardin du Luxembourg. For Tzara, this compression of time and space anticipates the cinematic jump cut, but also suggests an analogy with early Renaissance painting. ${ }^{52}$ Discussing the Coronation of the Virgin by Fra Angelico (c. 1434-35, Musée du Louvre, Paris), Tzara draws attention to images at the base of the painting (the predella) that depict scenes from the life of Saint Dominic. Like Rousseau's theatre, this sequence does not unfold in a continuous, linear narrative. Rather it compresses time and space, leaving place for the spectator to fill in the gaps through the work of his or her imagination. Applying this idea to Rousseau's play, he states: 'Après avoir été imprégnés d'une scène, le brusque transfert qu'on nous impose dans le passé ou l'avenir ou dans un endroit différent, suppose

50 Tzara, 'Le théâtre d'Henri Rousseau', p. 347.

${ }^{51}$ Tzara also identifies collage-like practices in the composition of the plays. He notes that the manuscript of Une visite à l'Exposition comprises corrections pasted onto the page 'faites au moyen de bouts de papier collés' (OC 4, p. 355) and that the manuscript of La vengeance d'une orpheline russe contains letters that have been written out by the author as if they were part of an actual correspondence: 'Dans le manuscrit de cette piece, les lettres que le protagoniste reçoit sont toutes écrites comme de véritables lettres datées et suivies d'une signature paraphée. Instinctive, la vérité de ces lettres pour Rousseau n'est ni ébranlée ni troublée par la fiction du théâtre. On songe au premier collages cubistes de Picasso et de Braque où le problème de la réalité objective et de la réalité construite du tableau est également posé quoique d'une manière plus théorique' (OC 4, p. 350).

${ }^{52}$ Examples of the jump cut can be found in the films of Georges Méliès produced at the end of the $19^{\text {th }}$ century. The technique became a signature style of Jean-Luc Godard in $\dot{A}$ bout du souffle in 1960. See Tzara's discussion of the links between Rousseau's art and cinema at $O C 4$, p. 349. 
de notre intelligence un effort d'abstraction, d'analogie et de déduction qui, pareil à une échelle par rapport à un escalier, supprime ce qui n'est pas essentiellement nécessaire...'. ${ }^{53}$ The metaphor of a ladder as opposed to a staircase is apt as it suggests a difference between the depiction of movement in, and pictorial coherence of, works by Rousseau (ladder) and Duchamp (staircase). Significantly, the temporal and spatial dislocations of Rousseau's collage-like paintings and theatrical works challenge the audience's expectation of a continuous narrative and, instead, constitute 'une offense à l'ordre sensoriel établi' ${ }^{54}$ In consequence, the works express the possibility of inhabiting a perspective on human existence that is liberated from a fixed spatial and temporal order. It is at this point that a link can be found between Tzara's conception of collage and his reconception of the trajectory of individual life.

Tzara examined this theme in his extended essay, Grains et Issues of 1935. A mixture of verse and prose, the essay describes itself as an 'experimental dream' and identifies a productive role for poetry in a utopian conception of society. Taking up ideas discussed above, social change is precipitated by a revolution that is artistic and phenomenological as well as political. Fernand Drijkoningen identifies two major preoccupations of the text: the ambition of giving precedence to the role of dreams in everyday life and 'la constitution d'une mythologie moderne capable de remplacer les mythes existants, surtout religieux, qui ne servent qu'à légitimer l'exploitation de l'homme par l'homme'. ${ }^{55}$ Emphasis on the role of dreams and on the unmediated expression of the unconscious brought the essay close to topics that were being pursued by Tzara's Surrealist colleagues. ${ }^{56}$ While it is beyond the scope of the present article to examine the details of

${ }^{53}$ Tzara, 'Le théâtre d'Henri Rousseau', p. 347. See also Ireson's discussion of cinema in 'Tristan Tzara and the Plays of the Douanier Rousseau', p. 619.

54 Tzara, 'Le rôle du temps et de l'espace dans l'œuvre du Douanier Rousseau', p. 337.

${ }^{55}$ Fernand Drijkoningen, 'Entre Surréalisme et Marxisme: Révolution et poésie selon Tzara', in Mélusine: Émmission-Réception, no. 1, ed. by Henri Béhar (Lausanne: Éditions l'Age d'Homme, 1979), pp. 265-280 (p. 273).

${ }^{56}$ Henri Béhar traces these connections in his Introduction to Tzara, Grains et Issues (Paris: Flammarion, 1981), pp. 19-37. On the reception of this difficult text following its publication see Émilie Frémont, 'Grains et Issues, Du recueil «Divers-Cosmique» à l'épopée épistémologique', in Europe, no. 1061-1062/Sept.-Oct, 2017, pp. 82-92. 
this complex text, the point I want to make for the purposes of this argument is the connection between Tzara's conception of individual liberty in Grains et Issues and the logic of collage that he pursues in the essays discussed above.

Once again inspired by Jungian theories concerning the relationship between conscious and unconscious thought, Tzara envisages psychological freedom in Grains et Issues as a release from distinctions between good and evil, beauty and ugliness, and the unfolding of linear history. ${ }^{57}$ Like the juxtaposition of elements within collage, a 'nouvelle forme transitoire de l'existence' will emerge when individuals abandon the idea that their lives move inexorably from birth to death. ${ }^{58}$ Just as conventional narrative is to be eliminated from theatrical and visual artworks, so too syntax will become 'reversible' and humans will be released from the tyranny of memory. ${ }^{59}$ Henri Béhar sums up this vision in the following terms: 'La parole [...] est abolie au profit d'une pensée sans langage [...]. L'espace et le temps y sont dilatés, la mémoire abolie, ainsi que la religion et sa brutale idée de la mort'. ${ }^{60}$

For Tzara, social regeneration was not simply a political matter (a Marxist transformation of capital and labour), but crucially a reorientation of humankind's perception of time and space. In a passage that anticipates the theatrical strategies of compression and simultaneity pursued in Rousseau's works, Tzara writes: 'Le temps ne sera plus emprisonné dans le système de marteau trop bien connu.... ${ }^{61}$ Neither syntax, nor time — nor human life itself — will unfold according to established trajectories of sense. This utopian image is not simply of a society that is liberated from capitalist domination, but of one that is released from the rules of grammar, from spatio-temporal conventions, and thus from familiar historical and personal narratives. This ideal is consistent with the ambitions of early Dada and develops Tzara's conception of collage as both a form and as an idea in

\footnotetext{
57 Tzara, Grains et Issues, p. 13.

58 Tzara, Ibid., p. 56.

59 Tzara, Grains et Issues, OC 3, p. 20 and p. 45.

${ }^{60}$ Henri Béhar, 'Introduction' to Tzara, Grains et Issues, p. 28. See also Papachristos, L'Inscription de l'oral et de l'écrit dans le théâtre de Tristan Tzara, p. 71: 'La trivialité éphémère de la vie acquiert la même puissance esthétique que l'art dont une des fonctions est de vaincre le temps qui passe'.

${ }^{61}$ Tzara, Grains et Issues, OC 3, p. 16.
} 
poetry, painting, and theatre. By elevating collage to the status of a metaphysical principle in Grains et Issues, Tzara outlines the terms of a new way of being - a new psychic life for the individual.

In a further echo of Tzara's preoccupation with the social dimension of collage, Grains et Issues reimagines urban life. The opening part of the extended dream sequence describes a new vision of the city and, by extension, the kinds of behavior that will take place within it. To take one example:

On se contentera d'arroser les jardins publics avec de l'encre et de construire sur la place de la Concorde un immense bateau dont les moteurs tourneront à sec. Des bandits enlèveront au lasso les banquiers qui se seront trop rapprochés et, à l'aide de béliers moyenâgeux, on détruira petit à petit cette merveille de la mécanique moderne. ${ }^{62}$

Just as Tzara's interest in collage focused on both the spontaneous transformation of spaces of human habitation and the creation of art objects from mass produced imagery, so too the reimagining of interpersonal relations in Grains et Issues is intimately connected to changes in the physical and visual environment of the city.

If Tzara's first discussion of collage constituted a dialogue with Aragon's writings on the subject, the ideal of a new social 'mythology' rooted in urban experience once again brought the two writers into the same orbit. Although the publication of Grains et Issues is typically understood as marking Tzara's break from Surrealism, an ongoing dialogue with Aragon's ideas remains clear in Tzara's continued exploration of the ways in which art can trigger social regeneration. ${ }^{63}$ The notion of a 'mythologie moderne' is central to this exchange between the two writers. Aragon's 'Préface à une mythologie moderne', first published in 1926 and reworked as the introduction to his Paysan de Paris in 1953 considered ways in which an individual's phenomenological experience of the urban environment could challenge habits of thought and behaviour. Crucial to Aragon's conception of a 'mythologie moderne' is a privileging of sensory experience over

\footnotetext{
62 Tzara, Grains et Issues, OC 3, p. 14.

${ }^{63}$ For further discussion of this split see Drijkoningen, 'Entre Surréalisme et Marxisme', pp. 266-7.
} 
rationality. In Le Paysan de Paris, the narrator's perambulations through the city expose him to a range of visual material ranging from public announcements to advertisements, pasted newspaper extracts, restaurant menus, legal notices, and private messages. This papering of the city is examined as both a trace of human life and a form of mark-making that gives rise to a 'metaphysics' of urban space. ${ }^{64}$

There are conceptual and terminological overlaps in the approaches of Tzara and Aragon to the ways in which the urban environment - and the individual's navigation of it - impacts on social life. For Aragon, an unstructured experience of the city (particularly of marginalized spaces and those threatened with demolition) reveals 'le sentiment moderne de l'existence. Une mythologie se noue et se dénoue. C'est une science de la vie qui n'appartient qu'à ceux qui n'en ont point l'expérience'. ${ }^{65}$ Writing in 1930, Aragon described this as part of an attempt to uncover the mythical character of 'modern sacred spaces' that had replaced religious sites associated with earlier generations. ${ }^{66}$ As Andreas Huyssen has noted, Aragon's focus on 'marginal urban spaces destined for destruction and rife with political protest' made Le Paysan de Paris a 'socially critical project' that extended beyond the work's emphasis on dreams and personal experience. ${ }^{67}$

While Aragon posits his dérive as a means of uncovering the emergence of new myths, Tzara's pursued a related, but different trajectory. As explained above, for Tzara, a 'mythologie moderne' was rooted in the spontaneous generation of visual forms that returned society and its styles of art production to originary experiences, a 'simulacre du culte ancien' ${ }^{68}$ Both writers identified the world of urban imagery as the locus of their quest for a transformative social mythology, yet Tzara used his conception of collage as a means of synthesizing aesthetics and utopian politics. While in 1930, Aragon looked back to Le Paysan de Paris and described it as 'une jacquerie de l'individualisme', Tzara remained

${ }^{64}$ Louis Aragon, Le Paysan de Paris, Euvres poétiques complètes, vol. I, ed. Olivier Barbarant et. al. (Paris: Gallimard, 2007), pp. 143-301 (p. 151).

${ }^{65}$ Aragon, 'Critique du Paysan de Paris', Euvres poétiques complètes, vol. 1, p. 297. ${ }^{66}$ Ibid.

${ }^{67}$ Andreas Huyssen, Miniature Metropolis: Literature in an Age of Photography and Film (Cambridge Mass: Harvard University Press, 2015), p. 190.

68 Tzara, 'Le papier collé ou le proverbe en peinture', p. 359. 
committed to the subversive role that collage could play in the restoration of collective rites, the uncovering of a new mode of thought, and, by extension, of social regeneration.

The new mythology envisaged by Tzara is motivated by a sense of humour and delight ('l'enchantement') that is borne of a liberation from time and memory. In Grains et Issues this is described in the following terms: ' ...l'inspiration et l'enchantement devienront les objectifs en vue d'une innocence totale, la force émouvante de l'esprit en mouvement...' ${ }^{69}$ This is closely related to the description of collage in 'Les papiers collés de Picasso', where the inauguration of a new mode of thinking is identified with the rediscovery of 'le domaine de la joie et son plaisir immédiat' ${ }^{70}$ Collage was the means by which the spontaneous transformation of the city streets extended into art and social life, uniting both under the banner of a distinctive 'mythologie moderne'.

Instead of simply revealing the mythical character of 'modern sacred spaces' as envisaged by Aragon, Tzara located his social revolution - and the visual means by which it could be effected - at the level of the human psyche. Rather than choosing between Communism and a commitment to principles that had informed both Dada and Surrealism, Tzara turned to collage as both a form and as an idea that could unite politics and aesthetics. In its ability to engage audiences' senses beyond the visual, collage was a means by which to identify human qualities that transcended geographical, class, and cultural boundaries. As a creative technique, it represented, therefore, 'le moment le plus poétique, le plus révolutionnaire' that could overturn the ways in which individuals related to each other and to the world around them. ${ }^{71}$

Tzara used a pun on the famous refrain from Charles Baudelaire's poem 'L'Invitation au voyage' to characterize Rousseau's creativity as a domain in which 'tout est jeu, calme, et volupté' (emphasis added). ${ }^{72}$ In similar terms, he associated collage with 'joy' and the ideal society of Grains et Issues as the blossoming of a 'volupté nouvelle'. ${ }^{3}$ This article has argued that for Tzara, a 'modern mythology' consisted in the proliferation

${ }^{69}$ Tzara, Grains et Issues, p. 25. For a discussion of humour in this vision of society see Ibid., pp. $47-8$.

70 Tzara, 'Les papiers collés de Picasso', p. 363.

71 Tzara, 'Le papier collé ou le proverbe en peinture', p. 360.

72 Tzara, 'Le théâtre d'Henri Rousseau', p. 352.

${ }^{73}$ Tzara, Grains et Issues, OC 3, p. 9. 
of collage-like structures that could alter the trajectory of human life and of social organization for the purpose of realizing 'une harmonie ample et fraternelle [...] aux frontières du possible'. ${ }^{74}$ Tzara's pursuit of these themes in both his poetry and critical writings was, in itself, a demonstration of the potential of art and the possibilities it could offer to initiate this particular kind of revolution.

${ }^{74}$ Tzara, 'Le théâtre d'Henri Rousseau', p. 356. 